\title{
Review Article \\ Chemistry and Functionality of Bioactive Compounds Present in Persimmon
}

\author{
Shazia Yaqub, Umar Farooq, Afshan Shafi, Kashif Akram, Mian Anjum Murtaza, \\ Tusneem Kausar, and Farzana Siddique
}

Institute of Food Science and Nutrition, University of Sargodha, Sargodha 40100, Pakistan

Correspondence should be addressed to Kashif Akram; kashifakramft@gmail.com

Received 12 October 2015; Revised 4 January 2016; Accepted 14 January 2016

Academic Editor: Volker Böhm

Copyright (C) 2016 Shazia Yaqub et al. This is an open access article distributed under the Creative Commons Attribution License, which permits unrestricted use, distribution, and reproduction in any medium, provided the original work is properly cited.

Extensive research has related the consumption of persimmon with the reduced risk of various diseases and particularly highlighted the presence of bioactive phenolic compounds for their therapeutic properties. Major phenolic compounds present in persimmon are ferulic acid, $p$-coumaric acid, and gallic acid. $\beta$-Cryptoxanthin, lycopene, $\beta$-carotene, zeaxanthin, and lutein are important carotenoids having antioxidant potential. They are important to prevent oxidation of low-density lipoproteins, safeguard beta cells of the pancreas, and reduce cardiovascular diseases, cancer, diabetes mellitus, and damage caused by chronic alcohol consumption. In this paper, the chemistry and health benefits of bioactive compounds present in persimmon are reviewed to encourage impending applications and to facilitate further research activities.

\section{Introduction}

Scientific research-based knowledge regarding the impact of food on human health has steered to substantial nutritional discoveries, product innovations, and mass production on an unprecedented scale [1]. The starring role of food for improving health by decreasing the risk of illness and disease has highlighted a new class of foods, now known as functional foods $[1,2]$. Functional foods and therapeutic agents are obtained either directly or indirectly from different natural sources. The therapeutic value of functional foods depends upon the presence of biologically active compounds (bioactive compounds). These bioactive compounds can offer various health benefits beyond the basic nutritional value of a food product [3-6].

Recently, natural bioactive compounds have been acknowledged with greater consideration [3]. Fruits and vegetables are vital parts of the diet and a rich source of bioactive compounds including dietary fiber, natural antioxidants, and various phytochemicals $[3,4,7]$. The individual phytochemicals that have been recognized are about 5000 in number, but large numbers of them are still unknown or unidentified [8]. Most bioactive compounds (phytochemicals, phenolics, and carotenoids) are nonnutritive but effective against different diseases $[9,10]$ as they play important roles as chemopreventive or chemotherapeutic agents [11].

Among the fruits, persimmon (Diospyros kaki) is a popular and widespread fruit that is enriched with many bioactive compounds, including polyphenols, terpenoids, steroids, flavonoids, carotenoids, minerals, and dietary fiber $[6,12]$. Some components like phenolics, antioxidants, sterols, and flavonoids have a beneficial effect on human health owing to their ability to prevent or control various ailments $[6,9]$. These bioactive components play an important role in reducing arterial stiffness and prevent oxidation of low-density lipoproteins (LDL) thus resulting in the prevention of atherosclerotic plaque formation [13]. Many phytochemicals also possess antimutagenic effects and regulate and trigger the immune system, thus resulting in the normal functioning of metabolism [14]. A number of them also serve as chemopreventive [15], anticancer, anti-inflammatory, and immunomodulatory agents $[16,17]$. Hence, persimmon, like other fruits, contains a number of functional compounds which are useful in promoting human health. This paper is aimed at appraising the chemical profile of persimmon fruit with reference to prospective bioactive components and at 
exploring their functionality and potential applications in disease prevention.

\section{Persimmon Origin and Production}

The Diospyros genus belongs to the Ebenaceae family and has more than 350 known species [12]. Diospyros kaki (persimmon) also known as Japanese or oriental persimmon is a deciduous fruit originated in Eastern Asia [18]. The regions with relatively mild summer and moderate winter are the most suitable for its growth. It is widespread in China, Japan, and Korea, where it is traditionally used for medicinal purposes [6]. Persimmon production is expanding at a rate of $5.76 \%$ annually, which makes it the 5 th fastest developing fruit crop in the world with a current annual production of 3.63 million metric tons [19]. China is ranked first in persimmon production in the world, with an annual production of 1.65 million metric tons [6].

Persimmon fruits are climacteric and ethylene regulates their process of ripening. Therefore, the shelf life of persimmon fruits can be increased by slowing the ripening process by inhibiting ethylene biosynthesis or its action, hence enhancing their storage life $[20,21]$. Persimmon is eaten as fresh or dried fruits. During drying, persimmon peel is removed; otherwise it produces bitter taste because of its astringency. Usually whole fruit and slices are dried to make dried persimmon products. Juices, sherbet, or puree is prepared from peeled persimmon pulp. However, unpeeled whole persimmon fruit can be used for persimmon vinegar and wine production [22].

\section{Physical Attributes}

The persimmon fruit looks like an orange red tomato with a pointed end. The whole fruit is edible, with the exemption of its seed and calyx. The color of the fruit varies from yellow or orange to deep red [23] depending upon the concentration of carotenoid contents [24]. Hence, higher carotenoid contents are imperative to get maximum market value of the fruit $[25$, 26].

\section{Classification Based on Taste}

The persimmon fruits are usually classified into astringent (A) and nonastringent (NA) varieties depending upon their taste. In the early stages of development, persimmon fruits accumulate large amounts of proanthocyanidins (PAs) in specialized tannin cells [27]. In both types of varieties, astringency decreases with maturation, resulting in about $70-90 \%$ decline in the total polyphenolic components like tannins [28]. Antioxidant activities of astringent persimmon are higher as compared to nonastringent varieties [29]. Astringent (A) type fruits remain rich in soluble PAs even after they reach the full-mature stage, whereas nonastringent (NA) type fruits lose these compounds before full maturation [30].

4.1. Astringent Persimmon. The astringency among different varieties of persimmon mainly depends on the concentration of water soluble tannins $[19,31]$ that are present in large tannin cells [32] in fruit flesh and peel and the level decreases as the fruit matures [31].

Among different varieties Mopan (Diospyros kaki L. cv. Mopan) is the main cultivar of astringent persimmon produced in Northern China [33] especially around Beijing [3436]. Hachiya is another variety of persimmon that cannot be consumed until being fully ripened because of its astringency. During the course of ripening, soluble tannins polymerize into insoluble ones resulting in reduced astringency [37]. Immature persimmon has proanthocyanidins (PAs) which are about 25\% (dry basis) of the fruit weight [27]. However, on maturation, this level drops below $1 \%$ [38], resulting in reduced antioxidant activity [39].

Moreover, on maturation, the fruit peel becomes thin and waxy, having thick jellylike pulpy flesh in it [40]. Large production losses take place during handling of too much soft fruits. To avoid these postharvest losses and to reduce the level of astringency, the use of ethylene or carbon dioxide, and so forth, along with the selection of appropriate cultivars, has been recommended [41]. The effectiveness of $\mathrm{CO}_{2}$ treatment to remove astringency is based on the insolubilization of tannins by the acetaldehyde generated during anaerobic respiration, which is triggered when fruit is exposed to a high $\mathrm{CO}_{2}$ atmosphere [42]. However, these treatments (ethylene, carbon dioxide) can generate undesirable changes, especially a characteristic yellow-orange color, due to changes in carotenoids contents. Novillo et al. [42] also identified a new disorder, known as "pinkish-bruising," in astringent persimmon that is associated with mechanical damage during the postharvest handling.

4.2. Nonastringent Persimmon. Nonastringent varieties include Lzu, 20th century, Fuyu (flat), Maekawa Jiro, and Fuyu Hana (pomelo). These are sweet in taste and must be eaten before full maturation; otherwise they become too soft to eat. In nonastringent types of persimmon, water soluble tannins completely disappear at maturity [31]. Their flesh is dark in color due to higher levels of $\beta$-cryptoxanthin and total carotenoids [43]. The level of these carotenoid contents increases up to 5.54 times from the first to the last stage of maturity during fruit development. According to findings by Zhao et al. [12] the level of carotenoid contents is higher (more than double) in nonastringent persimmons than astringent ones at each stage of development before ripening.

Fuyu is the most important nonastringent cultivar grown in Japan. They have a firm peel enclosing orange-yellow flesh and have a good (sweet) taste [44].

\section{Compositional Profile}

5.1. Persimmon Fruit. Persimmon fruit contains $79 \%$ water, $0.7 \%$ pectin, $0.4 \%$ protein, and crude fiber [31]. It is rich in vitamin A (217 RE) compared to apple (5 RE). Vitamin C contents vary from 7.5 to $70 \mathrm{mg}$ per $100 \mathrm{~g}$ of the fruit flesh depending upon the variety [39]. Some varieties are as rich as satsuma mandarin and strawberry in their vitamin C contents [25]. It also contains various bioactive substances (Table 1) 
TABLE 1: Nutritional value ${ }^{\mathrm{a}}$ per $100 \mathrm{~g}(3.5 \mathrm{oz})$ of persimmon fruit (Diospyros kaki, raw).

\begin{tabular}{lc}
\hline Energy & $293 \mathrm{~kJ}(70 \mathrm{kcal})$ \\
Carbohydrates & $18.59 \mathrm{~g}$ \\
$\quad$ Sugars & $12.53 \mathrm{~g}$ \\
$\quad$ Dietary fiber & $3.6 \mathrm{~g}$ \\
Fat & $0.19 \mathrm{~g}$ \\
$\quad$ Saturated & $0.02 \mathrm{~g}$ \\
Protein & $0.58 \mathrm{~g}$ \\
Riboflavin $\left(\mathrm{Vit}_{2} \mathrm{~B}_{2}\right)$ & $2.5 \mathrm{mg}(208 \%)$ \\
Folate $\left(\right.$ Vit. $\left.\mathrm{B}_{9}\right)$ & $8 \mu \mathrm{g}(2 \%)$ \\
Vitamin C & $7.5 \mathrm{mg}(9 \%)$ \\
Calcium & $8 \mathrm{mg}(1 \%)$ \\
Iron & $0.15 \mathrm{mg}(1 \%)$ \\
Sodium & $1 \mathrm{mg}(0 \%)$ \\
\hline
\end{tabular}

${ }^{\text {a }}$ Percentages are relative to US recommendations for adults (Source: [45]).

like vitamins (A, B complex, $\mathrm{C}, \mathrm{E}$, and $\mathrm{K}$ ) and minerals (zinc, copper, iron, magnesium, calcium, and phosphorus) that are valuable for the proper physiology of human health [45]. Proanthocyanidins (PAs) are potent antioxidants and show 20 and 50 times more activity than vitamins $\mathrm{C}$ and $\mathrm{E}$, respectively [46].

5.2. Persimmon Peel. The external layers of a fruit such as peel, shell, and hull that shield the inside materials generally contain enormous quantities of functional compounds [2]. Regarding the persimmon peel, it is considered as waste, yet it is receiving much attention because of its chemical composition $[47,48]$. The main constituent of peel is dietary fiber $(40.35 \% \mathrm{w} / \mathrm{w})$. In addition, high levels of antioxidants, including vitamin $\mathrm{C}$, total phenolics, and total carotenoids, are also present [49]. Among the phenolic compounds, caffeic acid, p-coumaric acid, ferulic acid, and gallic acid (Figure 1) are present in large quantities [50,51]. Proanthocyanidins (PAs) are condensed tannins that exhibit powerful antioxidant activities. These are largely present in the peel as compared to pulp [52]. The level of total carotenoids in persimmon peel is very high (about $340 \mathrm{mg} / 100 \mathrm{~g}$ of dried peels as $\beta$ carotene equivalents) as compared to the peels of other fruits like banana [53] and apple [54]. Among the carotenoids, $\beta$ cryptoxanthin is the highest (about $42 \%$ ), followed by zeaxanthin, lutein, and $\beta$-carotene (Figure 2) [55]. The quantity of bioactive compounds (biologically active components), especially carotenoids and polyphenols, is greater in the peel compared to the pulp [50]. Hence, persimmon peel should be consumed by individuals and used for industrial processing [47].

5.3. Persimmon Fruit Pulp. Persimmon pulp is rich in nutrients such as vitamin C $(70 \mathrm{mg} / 100 \mathrm{~g})$, vitamin A $(65 \mathrm{mg} /$ $100 \mathrm{~g})$, calcium $(9 \mathrm{mg} / 100 \mathrm{~g})$, and iron $(0.2 \mathrm{mg} / 100 \mathrm{~g})$ [56]. In the edible part (pulp) of the persimmon, the major phenolic acids are ferulic acid, $p$-coumaric acid, and gallic acid, and the antioxidant activity of these phenolic acids is affected by their chemical structures (number of hydroxyl groups attached).<smiles>O=C(O)c1cc(O)c(O)c(O)c1</smiles><smiles>O=C(O)/C=C/c1ccc(O)cc1</smiles><smiles>COc1cc(/C=C/C(=O)O)ccc1O</smiles><smiles></smiles><smiles>O=C(O)CCc1ccc(O)c(O)c1</smiles><smiles>O=C(O)c1ccc(O)c(O)c1</smiles>

Proanthocyanidins

FIGURE 1: Chemical structures of common phenolics in persimmon.

Carotenoids are the major pigment present in persimmon. They contribute to both color and nutritional value [5759]. Carotenoid contents rapidly increase as green mature fruit changes to soft mature persimmon, except for lutein and lycopene that decrease during fruit maturation [60]. Among them $\beta$-cryptoxanthin content is the highest (50\%), followed by lycopene (10\%), $\beta$-carotene $(10 \%)$, zeaxanthin (5\%), and lutein (5\%) [59]. They are all excellent lipid-soluble antioxidants, especially lutein, astaxanthin, and zeaxanthin, having the ability to scavenge free radicals in a lipid-soluble environment and thus preventing the oxidation of lipids. The final composition and concentration of carotenoid contents are properly regulated to some extent by the different developmental stages of plant tissues [61]. Carotenoids identified in persimmon fruits are cis-mutatoxanthin, antheraxanthin, zeaxanthin, neolutein, cryptoxanthins, $\alpha$-carotene, and $\beta$ carotene and also fatty acid esters of $\beta$-cryptoxanthin and zeaxanthin [62].

5.4. Persimmon Seeds. Palmitic acid, oleic acid, and linoleic acid are the major fatty acids found in persimmon seeds, ranging from $70.4 \%$ to $78.3 \%$ of total fatty acids [63]. Among the fatty acids, oleic acid plays a role in cancer prevention. The effect of oleic acid on the same lines of breast cancer cells was examined and it supported the theory that oleic acid is chemopreventative [64]. Moreover, omega-6 fatty acid (linoleic acid) diminishes the risk of cardiovascular diseases [65].

5.5. Persimmon Leaves. Persimmon leaves contain 4 flavonols [66]. The leaves of persimmon have been reported to 
<smiles>CC1=C(/C=C/C(C)=C/C=C/C(C)=C/C=C/C=C(C)/C=C/C=C(\C)CCC2=C(C)CCCC2(C)C)C(C)(C)CCC1</smiles><smiles>CC1=C(/C=C/C(C)=C/C=C/C(C)=C/C=C/C=C(C)/C=C/C=C(C)/C=C/C2=C(C)CCCC2(C)C(F)(F)F)C(C)(C)CCC1</smiles><smiles>CC(C=CC=C(C)C=CC=C(C)C=CC1=C(C)CCCC1(C(C)(C)C)C(C)(C)C)=CC=CC=C(C)C=C[C@H]1C(C)=CCCC1(C)C</smiles><smiles>CC1=C[C@@H](O)CC(C)(C)[C@H]1/C=C/C(C)=C/C=C/C(C)=C/C=C/C=C(C)/C=C/C=C(C)/C=C/C1=C(C)C[C@@H](O)CC1(C)C</smiles><smiles>CC1=C(/C=C/C(C)=C/C=C/C(C)=C/C=C/C=C(C)/C=C/C=C(C)/C=C/C2=C(C)C[C@@H](O)CC2(C)C)C(C)(C)C[C@H](O)C1</smiles><smiles>CC1=C(/C=C/C(C)=C/C=C/C(C)=C/C=C/C(C)=C/C=C/C=C(C)/C=C/C2=C([18OH])C[C@@H](O)CC2(C)C)C(C)(C)CCC1</smiles>

FIGURE 2: Chemical structures of common carotenoids in persimmon.

contain the following compounds: 40-dihydroxy-a-truxillic acid, tatarine $\mathrm{C}$, myricetin, annulatin, trifolin, astragalin, hyperin, isoquercetin, rutin, quercetin, kampferol, kakispyrone, and kaki saponin [67]. Leaves have been used for tea in Korea, since they were was thought to be effective against hypertension [68].

\section{Persimmon Bioactive Compounds}

Persimmon fruit is a good source of polyphenols [69]. The term "polyphenols" includes a large group of substances, and they all have more than one phenolic hydroxyl group bound to one or more benzene ring systems [70]. The phenolic compounds are secondary metabolites of plants $[71,72]$ and found in free and bound forms in persimmon fruit [73].

Persimmon phenols can be grouped as a function of their molecular complexity/weight. Thus, free phenolic acids, catechins, and hydrolyzable tannins are included in lowmolecular weight phenols while high-molecular weight phenols which are also called as condensed tannins or proanthocyanidins (PAs) are large polymers of catechins with or without galloylation [74]. One of the major components of condensed tannin in persimmon fruit was identified by Akagi et al. [75] during compositional study of persimmon 
with phloroglucinol. They characterized this component as novel epigallocatechin-3-O-gallate-phloroglucinol (EGCGP) adduct. Li et al. [76] also reported that the persimmon pulp is comprised of flavan-3-O-galloylated extenders, flavan3-ol and flavonol terminal units, and A-type interflavan linkages which are condensed tannins with high-molecular weight.

Structurally, phenols contain an aromatic ring having hydroxyl substituents, ranging from simple to highly polymerized compounds [77]. The naturally present compounds form linkages with saccharides and might be functional derivatives like esters and methyl esters. Hence, the extensive variety of phenolic compounds occurring in nature is the result of this structural assortment. These compounds are categorized in several groups. Out of them, phenolic acids, flavonoids, and tannins are considered as the main dietary components [78].

Phenolic acids are non-flavonoid polyphenolic compounds comprised of 2 subgroups: hydroxybenzoic and hydroxycinnamic acids. Hydroxybenzoic acids contain gallic, $p$-hydroxybenzoic, protocatechuic, vanillic, and syringic acids, in which they all have the C6-C1 structure. Hydroxycinnamic acids, instead, are aromatic compounds like caffeic, ferulic, $p$-coumaric, and sinapic acids with a 3-carbon (C6-C3) side chain [78]. The structure of phenolic compounds is a vital factor affecting radical-scavenging and metal chelating activities and, hence, it is referred to as having a structure-activity relationship. In the case of phenolic acids, the antioxidant activity is influenced by the numbers and positions of the hydroxyl groups with respect to the carboxyl functional group [47]. Hence, they give their hydrogen atoms to scavenge free radicals as shown in Figure 1.

Flavonoids have the $\mathrm{C} 6-\mathrm{C} 3-\mathrm{C} 6$ general structural backbone in which the two C6 units (Ring A and Ring B) are of phenolic nature. Flavonoids can be further divided into different subgroups on basis of variations in chromane ring and hydroxylation pattern. Flavonoids can be further divided into different subgroups such as anthocyanins, flavan-3-ols, flavones, flavanones, and flavonols. While the vast majority of the flavonoids have their Ring B attached to the C2 position of Ring C; these basic structures of flavonoids are aglycones; however, in plants, most of these compounds exist as glycosides. Biological activities of these compounds, including antioxidant activity, depend on both the structural variation and the glycosylation patterns [79].

Tannins, the third important group of phenolics, are segmented as hydrolysable and condensed tannins, which are esters of gallic acid and polymers of polyhydroxyflavan-3ol monomers, respectively. The third segment, phlorotannins comprised of phloroglucinol, is found in brown algae. However, these are insignificant regarding human diet $[75,76]$. Tannins are present in persimmon prolonged life and reduced the incidence of stroke in hypertensive rats [80,81]. This effect was attributed to the fact that persimmon tannins are 20 times more potent than antioxidant vitamin $\mathrm{E}$ [82]. The persimmon tannin is composed mostly of epicatechin, epicatechin-3O-gallate, epigallocatechin, and epigallocatechin-3-O-gallate [83].

\section{Therapeutic Effects of Persimmon}

Persimmon has been used for various medicinal purposes (Table 2) owing to the therapeutic properties such as diuretic effect, blood pressure-lowering capability and the cough treatment, viral and bacterial infectious diseases [84], and dental caries [85]. Various bioactive compounds including polyphenols, carotenoids, vitamins, and dietary fiber in the fruit are responsible for beneficial properties [49]. Subagio et al. [52] reported the protective effect of proanthocyanidin from persimmon peel against DNA damage and SIRT expression in the aging process.

The persimmon leaves are a good source of antioxidants [102] while the seed extracts have a strong radical-scavenging activity [104]. The fruits are a rich source of dietary carotenoids (âa-carotene, â-cryptoxanthin, zeaxanthin, lutein, and lycopene), which have been implicated in the reduction of degenerative human diseases [91]. The concentration of $\hat{a}-$ carotene and $\hat{a}$-cryptoxanthin is so high that $100 \mathrm{~g}$ of pulp provides $10 \%$ of the recommend daily allowance provitamin A [105].

Persimmon fruit can be used in the manufacturing of products with functional characteristics because of its bioactive properties. It is an excellent source of ascorbic acid, tannins, and carotenoids, having healthy aspects owing to their antioxidant and other health protecting activities [6].

7.1. Diabetes. Diabetes mellitus is a chronic disease and the reason behind that is inherited and/or acquired insufficient insulin production by the pancreas, or by the incompetence of the insulin produced. Such a deficiency results in raised concentrations of glucose in the blood, which sequentially damage many of the body's systems, particularly the blood vessels and nerves [106]. When body's defense systems neither detoxify the reactive intermediates nor repair the resulting damage from reactive oxygen species (ROS), then such an imbalance condition is known as oxidative stress, responsible for diabetes mellitus and related complications [107].

Along with insulin, many other agents like sulfonylurea and biguanide can be used to reduce blood glucose level in order to treat diabetes. These hypoglycemic agents have considerable side effects [108]. In chronic diabetes, these hypoglycemic agents sometimes become ineffective [109]. Therefore, the demand of such hypoglycemic agents which have side effects and are either made artificially or from natural source is decreasing day by day [110]. Hence, there is need of natural agents like plant and plant based materials which can show more potential for control and treatment of diabetes and its complications with no side effects [111]. Since several years, herbal remedies including different medicinal plants or their extracts have been taken orally in order to treat diabetes. The search for effective natural hypoglycemic agent is under consideration as recommended by WHO [112]. Recently great attention has been paid to a number of nonvitamin antioxidants, widely distributed in natural sources like fruit, vegetables, and spices, having the ability to enhance the antioxidative defense mechanism at cellular level without side effects [113]. The main group of compounds that act primarily as free radical terminator or antioxidants is plant phenolics. 
TABLE 2: Various bioactive compounds present in persimmon and their functional properties.

\begin{tabular}{|c|c|c|}
\hline Source & Health benefits & Reference \\
\hline \multicolumn{3}{|l|}{ Extracted polyphenol } \\
\hline$p$-Coumaric & Prevention of oxidative stress related diseases including diabetes & {$[86]$} \\
\hline Tannins & Scavenging action against active oxygen free radicals & {$[82,87,88]$} \\
\hline Tannin & $\begin{array}{l}\text { Assists the neuronal degeneration and karyopyknosis in cells, reduction of } \\
\text { thickness of skin epidermis }\end{array}$ & [89] \\
\hline Flavonoids & Scavenging action against active oxygen free radicals & {$[82,87,88]$} \\
\hline \multicolumn{3}{|l|}{ Persimmon fruit } \\
\hline \multirow{8}{*}{ Whole fruit } & Possesses antitumor effects due to betulinic acid & {$[47,90]$} \\
\hline & Blood pressure-lowering and diuretic effects, also effective for coughs treatment & [91] \\
\hline & $\begin{array}{l}\text { Has antioxidative potentials due to compounds like vitamin A, beta-carotene, } \\
\text { lycopene, lutein, zeaxanthin, and cryptoxanthin }\end{array}$ & {$[92]$} \\
\hline & Exhibits hypolipidemic and antioxidant properties & {$[50,82]$} \\
\hline & Contains nutritional antioxidant vitamins, polyphenols, and dietary fiber & {$[93,94]$} \\
\hline & Reduction of patches of pigmentation on skin & [95] \\
\hline & $\begin{array}{l}\text { Has ability to dilate the blood vessels near the surface of the skin, thereby allowing } \\
\text { more blood to flow through the skin, where it can be cooled by the air (antifebrile) }\end{array}$ & {$[96]$} \\
\hline & Reduction of degenerative disease in human beings & {$[91,97-99]$} \\
\hline Fruit peel powder & Pharmacological potential such as antioxidant and hypocholesterolemic & {$[51,95,100]$} \\
\hline $\begin{array}{l}\text { Water-soluble } \\
\text { polysaccharides extracted } \\
\text { from persimmon fruits }\end{array}$ & Have ability to alter or regulate immune functions (immunomodulatory activity) & {$[85]$} \\
\hline Persimmon vinegar & $\begin{array}{l}\text { Has antitumor and antioxidative effects and also prevents metabolic disorder } \\
\text { induced by chronic alcohol administration }\end{array}$ & [101] \\
\hline \multicolumn{3}{|l|}{ Plant and leaf extracts } \\
\hline \multirow{2}{*}{ Persimmon leaf tea } & Prevents hardening of the arteries which ultimately lowers the blood pressure & {$[95]$} \\
\hline & Good source of natural antioxidants & {$[102]$} \\
\hline Persimmon plant extracts & $\begin{array}{l}\text { Contain antitumor and multidrug resistance-reversing agents } \\
\text { Stop oxidative damage of DNA }\end{array}$ & [47] \\
\hline Persimmon calyx extracts & Anticonvulsants & {$[103]$} \\
\hline $\begin{array}{l}\text { Persimmon plant } \\
\text { supplemented to a diet }\end{array}$ & Hypocholesterolemic and antioxidative effects & {$[82]$} \\
\hline \multirow{2}{*}{ Persimmon seeds } & Contain omega 6 fatty acids like palmitic acid, oleic acid, and linoleic acid & {$[63]$} \\
\hline & Radical-scavenging activity & [104] \\
\hline
\end{tabular}

Among fruits, persimmon is comprised of a large number of biologically active polyphenols like tannins and flavonoids having good antioxidant potential. These polyphenols prevent the diabetes resulting from oxidative stress [86], since these work as antioxidants preventing the peroxidation of lipids by the donation of a hydrogen atom from hydroxyl group attached to their chemical structure rapidly and form peroxyl radical (ROO) that ultimately leads to the formation of alkyl (aryl) hydroperoxide (ROOH), as shown in the following reaction:

$$
\mathrm{ROO}^{-}+\mathrm{PPH} \longrightarrow \mathrm{ROOH}+\mathrm{PP}^{-}
$$

The phenolic antioxidant (PPH) itself changes into polyphenol phenoxyl radical (PP), which becomes stable after donating a hydrogen atom, by conversion into quinines, and it hinders the initiation of new chain reaction by reacting with another radical in which another phenoxyl radical is also included $[114,115]$.
Gorinstein et al. [49] reported that a 2-week intake of persimmon peel supplemented diet considerably reduces food intake, blood glucose, total cholesterol, and plasma triglycerides level in diabetics. The researchers concluded that persimmon peel rich in high level of antioxidant and dietary fiber with antidiabetic properties may be characterized as a possible nutritional supplement for improving diabetic complications and hyperglycemia.

In fresh persimmon leaves most of the polyphenols are found to be water soluble. The chief components in persimmon leaf tea are unique proanthocyanidin oligomers and oral administration of this tea along with starch resulted in a dose-dependent decline in the blood glucose level in Wistar rats [116].

7.2. Atherosclerosis. Inflammation and high levels of oxidative stress are a major initiator of cardiovascular diseases like atherosclerosis that ultimately leads to coronary artery 
disease (CAD). In such condition, the oxidative stress is characterized by the accumulation of metabolites (from the oxidation of proteins and lipids) and macrophages. According to the hypothesis of oxidative modification, the early event which initiates the development of atherogenesis (development of atheromatous plaques) is the oxidative breakdown of low-density lipoproteins. Reactive oxygen species in the vessel wall have been considered to be one of the most important causes of vascular dysfunction [117].

Dietary components having antioxidant properties as the polyphenols are receiving a lot of attention because of their ability to reduce cardiovascular diseases $[118,119]$. When diet rich in fiber is largely consumed, it results in prevention and treatment of diverticular and coronary heart diseases [120]. Coronary atherosclerosis, especially, is inhibited by preventing oxidation of low-density lipoprotein (LDL) and by nutritional antioxidants like phenolics [121] and vitamins A, $\mathrm{C}$, and E [122].

Hence, many reports have shown that if intake of vegetables and fruits is increased in diet, then chances of coronary heart diseases could greatly be reduced [123]. According to Hertog et al. [124] if $100 \mathrm{~g}$ of persimmon is consumed regularly, then it will be sufficient to inhibit occlusion of arteries. In young fruits of persimmon (Diospyros $k a k i)$ tannin is found to have the ability of bonding bile acid [83].

It has been established that addition of persimmon in the diet hinders the increase in plasma lipid level and hence works as antiatherosclerosis [80, 124], which reduces the chances of mortality by the action of polyphenols [125]. Matsumoto et al. [82] also reported that the persimmon peel supplemented diet shows hypocholesterolemic and antioxidative effect.

Total dietary fibers including soluble and insoluble, total phenolics including epicatechin, gallic, and $p$-coumaric acids, and concentrations of minerals like $\mathrm{Na}, \mathrm{K}, \mathrm{Mg}, \mathrm{Ca}, \mathrm{Fe}$, and $\mathrm{Mn}$ are high in peel, pulp, and whole persimmon fruit compared to apple [50]. Hence, persimmon must be given preference over apples and some other fruits in selecting an antiatherosclerotic diet. Liu [126] reported decline in blood triglyceride and total cholesterol contents after intake of persimmon vinegar (PV) for 6 weeks.

7.3. Cancer. In recent years, persimmon has been the focus of attention for potential medicinal applications for prevention of cancer [47]. Carotenoids are nature's most widespread pigments and have also received substantial attention because of both their provitamin and antioxidant roles [127]. Carotenoids possess antioxidant properties that have been associated with cellular protection [128], regulation of cell growth, differentiation, and apoptosis [129].

Not only are the carotenoid contents responsible for the superficial appearance (color) and nutritional quality of fruit [130] but also they provide potential health benefits and disease prevention by quenching singlet oxygen and scavenging free radicals [131]. Chemoprotective effects of persimmon against various forms of cancer are due to the carotenoid contents [132, 133]. Persimmon was shown to be effective in the treatment of prostate and breast cancers
[134], oral carcinoma cells [47], human lymphoid leukemia cells [135], and precancerous colon polyps in women [136]. The bioactive compounds in persimmon may also affect multidrug resistant (MDR) inhibiting activity. It enhances the accumulation of cancer cells due to the reduced activity of efflux pumps. MDR inhibitors from persimmon may help to treat noncurable cancer because of the modulating effects [47]. The calyx (persimmon) extracts act as anticonvulsants and may alleviate the side effects of barbituric acid compounds [103].

\section{Other Health Promoting Properties}

Dried persimmon snacks were found to be effective in reducing the concentration of alcohol in the blood [55]. Similarly, Matsuno [137] observed that kaki-tannin found in persimmon fruit flesh and leaves was soluble in artificial stomach liquid and reduced blood alcohol (40\%) and acetaldehyde contents (30\%). Dietary intake of persimmon tannin was found to prevent hypercholesterolemia in some animal models and humans [138].

Some carotenoids present in persimmon are precursors of vitamin A [139] and also have immunoregulatory [140] and antiaging effects [141]. Carotenoids are inversely linked with inflammation, atherosclerosis, cardiovascular diseases, sarcopenia, and mortality. Carotenoid supplementation improves the antioxidant status and reduces lipid peroxidation.

Carotenoids like $\beta$-carotene, $\alpha$-carotene, $\beta$-cryptoxanthin, lycopene, and lutein (Figure 2) have been found to be associated with inflammation and mortality risks [142]. In addition, lutein (carotenoids) present in persimmon peel can help protect eye vision [143].

\section{Persimmon Leaves and Health}

Persimmon leaves and extracts are being used as a green tea, oriental medicines, deodorants, antiallergic substrates, and cosmetics (especially for dermatitis) as they prevent skin problems and have an antiwrinkle effect $[68,143]$ and skin whitening effect [72]. The leaves are brewed into a beverage to release their antioxidant activity and antitumor effects and to inhibit angiotensin converting enzymes as well as alpha amylase [66]. The leaves of persimmon possess antithrombotic activity. Arakawa et al. [144] demonstrated that a 10,000 $\mathrm{D}$ anticoagulant fraction has been purified from the leaves that inhibited thrombin-catalyzed fibrin formation with a competitive inhibition pattern. Based on their antimicrobial properties, persimmon leaf-based products have been incorporated into athlete's foot socks and soaps, and persimmon leaves have been used as a sushi ingredient [145].

\section{Unripen Persimmons and Health Issues}

Bezoars are thick hard masses formed in gastrointestinal tract usually the stomach [146]. Patients who have undergone stomach surgery and have delayed gastric emptying are often more prone to the development of bezoars [147]. Phytobezoars are the most common types of bezoars and 
these are composed of skins, seeds, and vegetative matter including lignin, cellulose, hemicelluloses, tannins, and other nondigestible matter from fruits and vegetables ingested. Diospyrobezoars are a type of phytobezoars related to the consumption of persimmon fruit and are common worldwide. These are more difficult to treat because of their hard consistency [146, 148, 149]. Most bezoars in animals are caused by hairs.

When unripe astringent persimmon, having a high level of tannin, is ingested, a coagulum is formed in the stomach due to the contact of tannin and shibuol with hydrochloric acid that accumulates cellulose, hemicellulose, and protein [150]. Phytobezoars may require surgical removal or endoscopic treatment as they are usually resistant to drug treatment [151]. Han et al. [152] suggested a nonsurgical approach for cases of persimmon phytobezoar small intestinal obstruction with its partial dissolution of a bezoar by performing oral and injected Coca-Cola therapy.

\section{Conclusion}

Bioactive compounds particularly phenolics (ferulic, $p$ coumaric, and gallic acids) and carotenoids ( $\beta$-cryptoxanthin, lycopene, $\beta$-carotene, and lutein) are of major interests in persimmon fruit. These valued bioactive components have strong antioxidant potential which relates to the variety, stage of maturity, and fruit parts. These functional compounds can play a significant role in preventing and curing various ailments like diabetes, hypercholesterolemia, and cancer. Hence, the known impact of natural bioactive compounds to improve human health, has introduced a substantial area of research resulting in extensive advances in biochemical and nutritional sciences.

\section{Conflict of Interests}

The authors declare that there is no conflict of interests regarding the publication of this paper.

\section{References}

[1] S. Lordan, R. P. Ross, and C. Stanton, "Marine bioactives as functional food ingredients: potential to reduce the incidence of chronic diseases," Marine Drugs, vol. 9, no. 6, pp. 1056-1100, 2011.

[2] S. Yaqub, U. Farooq, T. Kausar, Z. Hayat, M. Jaskani, and S. M. Ullah, "Hypocholestrolemic effect of persimmon peel powder in rabbits," Journal of Science International, vol. 25, no. 3, pp. 605-609, 2013.

[3] M. S. Butt, M. T. Sultan, M. Aziz et al., "Persimmon (Piospyros kaki) fruit: hidden phytochemicals and health claims," EXCLI Journal, vol. 14, pp. 542-561, 2015.

[4] A. H. A. Hadi, M. E. Duru, and A. B. Martin-Diana, "Bioactive natural products," Journal of Chemistry, vol. 2013, Article ID 208507, 1 page, 2013.

[5] M. R. Segura Campos, J. Ruiz Ruiz, L. Chel-Guerrero, and D. Betancur Ancona, "Coccoloba uvifera (L.)(Polygonaceae) fruit: phytochemical screening and potential antioxidant activity," Journal of Chemistry, vol. 2015, Article ID 534954, 9 pages, 2015.
[6] S. Karaman, Ö. S. Toker, F. Yüksel, M. Çam, A. Kayacier, and M. Dogan, "Physicochemical, bioactive, and sensory properties of persimmon-based ice cream: technique for order preference by similarity to ideal solution to determine optimum concentration," Journal of Dairy Science, vol. 97, no. 1, pp. 97-110, 2014.

[7] M. C. Caruso, F. Galgano, M. Pecora, R. Tolve, M. Verrastro, and F. Favati, "Improvement of analytical methods for the determination of polyphenolic bioactive compounds in berry fruits," Journal of Chemistry, vol. 2015, Article ID 384051, 6 pages, 2015.

[8] R. H. Liu, "Health benefits of fruit and vegetables are from additive and synergistic combinations of phytochemicals," The American Journal of Clinical Nutrition, vol. 78, no. 3, pp. 517S520S, 2003.

[9] L. Dauchet, P. Amouyel, S. Hercberg, and J. Dallongeville, "Fruit and vegetable consumption and risk of coronary heart disease: a meta-analysis of cohort studies," Journal of Nutrition, vol. 136, no. 10, pp. 2588-2593, 2006.

[10] A. Denny and J. Buttriss, "Plant foods and health: focus on plant bioactives," EU 6th Framework Food Quality and Safety Thematic Priority Contract FOOD-CT-2005-513944, European Food Information Resource (EuroFIR) Consortium, 2007.

[11] S. M. K. Rates, "Plants as source of drugs," Toxicon, vol. 39, no. 5, pp. 603-613, 2001.

[12] D. Zhao, C. Zhou, Y. Sheng, G. Liang, and J. Tao, "Molecular cloning and expression of phytoene synthase, lycopene betacyclase, and beta-carotene hydroxylase genes in persimmon (Diospyros kaki L.) fruits," Plant Molecular Biology Reporter, vol. 29, no. 2, pp. 345-351, 2011.

[13] K. Suzuki, S. Tsubaki, M. Fujita, N. Koyama, M. Takahashi, and K. Takazawa, "Effects of safflower seed extract on arterial stiffness," Vascular Health and Risk Management, vol. 6, no. 1, pp. 1007-1014, 2010.

[14] M. S. Butt and M. T. Sultan, "Green tea: nature's defense against malignancies," Critical Reviews in Food Science and Nutrition, vol. 49, no. 5, pp. 463-473, 2009.

[15] I. Raskin, D. M. Ribnicky, S. Komarnytsky et al., "Plants and human health in the twenty-first century," Trends in Biotechnology, vol. 20, no. 12, pp. 522-531, 2002.

[16] S. Parab, R. Kulkarni, and U. Thatte, "Heavy metals in herbal medicines," Indian Journal of Gastroenterology, vol. 22, no. 3, pp. 111-112, 2003.

[17] K. L. Miller, R. S. Liebowitz, and L. K. Newby, "Complementary and alternative medicine in cardiovascular disease: a review of biologically based approaches," American Heart Journal, vol. 147, no. 3, pp. 401-411, 2004.

[18] D. L. Guo and Z. R. Luo, "Genetic relationships of the Japanese persimmon Diospyros kaki (Ebenaceae) and related species revealed by SSR analysis," Genetics and Molecular Research, vol. 10, no. 2, pp. 1060-1068, 2011.

[19] M. J. Li, D. Liang, F. Pu, F. W. Ma, C. M. Hou, and T. Lu, "Ascorbate levels and the activity of key enzymes in ascorbate biosynthesis and recycling in the leaves of 22 Chinese persimmon cultivars," Scientia Horticulturae, vol. 120, no. 2, pp. 250256, 2009.

[20] Z. Luo, "Effect of 1-methylcyclopropene on ripening of postharvest persimmon (Diospyros kaki L.) fruit," LWT_Food Science and Technology, vol. 40, no. 2, pp. 285-291, 2007. 
[21] A. T. Oz, "Combined effects of 1-methyl cyclopropene (1-MCP) and modified atmosphere packaging (MAP) on different ripening stages of persimmon fruit during storage," African Journal of Biotechnology, vol. 10, no. 5, pp. 807-814, 2011.

[22] M. S. Akter, M. Ahmed, and J. B. Eun, "Dietary fibre components, antioxidant activities and hydration properties of ripe persimmon (Diospyros kaki L. cv. Daebong) peel powders as affected by different washing treatments," International Journal of Food Science and Technology, vol. 45, no. 7, pp. 1464-1471, 2010.

[23] K. Yonemori, A. Sugiura, and M. Yamada, "Persimmon genetics and breeding," Plant Breeding Reviews, vol. 19, pp. 191-225, 2000.

[24] P. Thomas and T. S. Chen, "Quantitative analyses of major carotenoid fatty acid esters in fruits by liquid chromatography: persimmon and papaya," Journal of Food Science, vol. 53, no. 6, pp. 1720-1722, 1988.

[25] T. Nakagawa, A. Nakatsuka, K. Yano et al., "Expressed sequence tags from persimmon at different developmental stages," Plant Cell Reports, vol. 27, no. 5, pp. 931-938, 2008.

[26] R. Veberic, J. Jurhar, M. Mikulic-Petkovsek, F. Stampar, and V. Schmitzer, "Comparative study of primary and secondary metabolites in 11 cultivars of persimmon fruit (Diospyros kaki L.)," Food Chemistry, vol. 119, no. 2, pp. 477-483, 2010.

[27] A. Ikegami, S. Eguchi, A. Kitajima, K. Inoue, and K. Yonemori, "Identification of genes involved in proanthocyanidin biosynthesis of persimmon (Diospyros kaki) fruit," Plant Science, vol. 172, no. 5, pp. 1037-1047, 2007.

[28] A. Sattar, N. Bibi, and M. A. Chaudry, "Phenolic compounds in persimmon during maturation and on-tree ripening," Food / Nahrung, vol. 36, no. 5, pp. 466-472, 1992.

[29] Y.-S. Park, S.-T. Jung, S.-G. Kang et al., "Drying of persimmons (Diospyros kaki L.) and the following changes in the studied bioactive compounds and the total radical scavenging activities," LWT-Food Science and Technology, vol. 39, no. 7, pp. 748$755,2006$.

[30] A. Ikegami, T. Akagi, D. Potter et al., "Molecular identification of 1-Cys peroxiredoxin and anthocyanidin/flavonol 3-Ogalactosyltransferase from proanthocyanidin-rich young fruits of persimmon (Diospyros kaki Thunb.)," Planta, vol. 230, no. 4, pp. 841-855, 2009.

[31] T. Radha and L. Mathew, Fruit Crops, Horticulture Science Series, Jai Baharat Press, 2007.

[32] H. Yakushiji, "Recent persimmon research in Japan," Japanese Journal of Plant Science, vol. 1, pp. 42-62, 2007.

[33] X. N. Chen, J. F. Fan, X. Yue, X. R. Wu, and L. T. Li, "Radical scavenging activity and phenolic compounds in persimmon (Diospyros kaki L. cv. Mopan)," Journal of Food Science, vol. 73, no. 1, pp. C24-C28, 2008.

[34] H. R. Wang, P. Leng, and C. S. Wang, "Effect of absorbents on storage quality of the Mopan persimmon," Journal Shanxi Agriculture and Science, vol. 33, no. 1, pp. 59-61, 2005.

[35] X. H. Guo, S. Z. Fang, J. Wang, X. X. Guo, L. Q. Xu, and L. Yuan, "Study on the infection of the Mopan persimmon quality by carbon dioxide," Food Research Developments, vol. 27, pp. 156159, 2006.

[36] S. Li, P. Zhang, J. K. Li, L. Wang, and Y. F. Huang, "Effect of 1-methylcyclopropene for the Mopan persimmon crispinesskeeping under ambient temperature," Storing Process, vol. 6, pp. 13-16, 2006.
[37] J. L. Vázquez-Gutiérrez, I. Hernando, and A. Quiles, "Changes in tannin solubility and microstructure of high hydrostatic pressure-treated persimmon cubes during storage at $4^{\circ} \mathrm{C}$," European Food Research and Technology, vol. 237, no. 1, pp. 9-17, 2013.

[38] N. Bibi, A. B. Khattak, and Z. Mehmood, "Quality improvement and shelf life extension of persimmon fruit (Diospyros kaki)," Journal of Food Engineering, vol. 79, no. 4, pp. 1359-1363, 2007.

[39] S. Kondo, H. Yoshikawa, and R. Katayama, "Antioxidant activity in astringent and non-astringent persimmons," Journal of Horticultural Science and Biotechnology, vol. 79, no. 3, pp. 390-394, 2004.

[40] X. Wei, F. Liu, Z. Qiu, Y. Shao, and Y. He, "Ripeness classification of astringent persimmon using hyperspectral imaging technique," Food and Bioprocess Technology, vol. 7, no. 5, pp. 1371-1380, 2014.

[41] K. P. Wright and A. A. Kader, "Effect of controlled-atmosphere storage on the quality and carotenoid content of sliced persimmons and peaches," Postharvest Biology and Technology, vol. 10, no. 1, pp. 89-97, 1997.

[42] P. Novillo, A. Salvador, E. Llorca, I. Hernando, and C. Besada, "Effect of $\mathrm{CO}_{2}$ deastringency treatment on flesh disorders induced by mechanical damage in persimmon. Biochemical and microstructural studies," Food Chemistry, vol. 145, pp. 454463, 2014.

[43] C. J. Xu and S. L. Zhang, "Carotenoid biosynthesis and its regulation in plants," Plant Physiology and Communication, vol. 36, pp. 64-70, 2000.

[44] E. Bellini, G. Giannelli, and E. Picardi, "Panoramica varietale del Kaki nel mondo e orientamenti produttivi per l'Italia," L'informatore Agrario, vol. 44, no. 47, pp. 47-88, 2011.

[45] USDA-Agriculture Research Service, National Agricultural Library, Beltsville, Md, USA, vol. 44, pp. 47-88, 1998.

[46] M. Kawase, N. Motohashi, K. Satoh et al., "Biological activity of persimmon (Diospyros kaki) peel extracts," Phytotherapy Research, vol. 17, no. 5, pp. 495-500, 2003.

[47] W. Bei, W. Peng, Y. Ma, and A. Xu, "Flavonoids from the leaves of Diospyros kaki reduce hydrogen peroxide-induced injury of NG108-15 cells," Life Sciences, vol. 76, no. 17, pp. 1975-1988, 2005.

[48] S.-O. Lee, S.-K. Chung, and I.-S. Lee, "The antidiabetic effect of dietary persimmon (Diospyros kaki L. cv. sangjudungsi) peel in streptozotocin-induced daibetic rats," Journal of Food Science, vol. 71, no. 3, pp. S293-S298, 2006.

[49] S. Gorinstein, Z. Zachwieja, M. Folta et al., "Comparative contents of dietary fiber, total phenolics, and minerals in persimmons and apples," Journal of Agricultural and Food Chemistry, vol. 49, no. 2, pp. 952-957, 2001.

[50] H. Leontowicz, S. Gorinstein, A. Lojek et al., "Comparative content of some bioactive compounds in apples, peaches and pears and their influence on lipids and antioxidant capacity in rats," Journal of Nutritional Biochemistry, vol. 13, no. 10, pp. 603610, 2002.

[51] Y. A. Lee, E. J. Cho, and T. Yokozawa, "Protective effect of persimmon (Diospyros kaki) peel proanthocyanidin against oxidative damage under $\mathrm{H}_{2} \mathrm{O}_{2}$-induced cellular senescence," Biological and Pharmaceutical Bulletin, vol. 31, no. 6, pp. 1265-1269, 2008.

[52] A. Subagio, N. Morita, and S. Sawada, "Carotenoids and their fatty-acid esters in banana peel," Journal of Nutritional Science and Vitaminology, vol. 42, no. 6, pp. 553-566, 1996. 
[53] Y. J. Yang and S. J. Kim, "Changes in chlorophyll and carotenoid contents during cold and CA storage, and characterization of the carotenoids in the peel of 'Fuji' apple fruit," Journal of Korean Society and Horticultural Science, vol. 36, pp. 500-505, 1995.

[54] Y. C. Kim, J. B. Kim, K. J. Cho, I. S. Lee, and S. K. Chung, "Carotenoid content of Korean persimmon peel and their changes in storage," Food Science and Biotechnology, vol. 11, no. 5, pp. 477-479, 2002.

[55] J. Tous and L. Ferguson, "Mediterranean fruits," in Progress in New Crops, J. Janick, Ed., pp. 416-430, ASHS Press, Arlington, Va, USA, 1996.

[56] B. Yuan, H. L. Xu, and S. P. Leng, "Content and chemical composition of carotenoids in persimmon fruit," Chinese Agricultural Science Bulletin, vol. 22, pp. 277-280, 2006 (Chinese).

[57] D. Zhao, C. Zhou, and J. Tao, "Carotenoid accumulation and carotenogenic genes expression during two types of persimmon fruit (Diospyros kaki L.) development," Plant Molecular Biology Reporter, vol. 29, no. 3, pp. 646-654, 2011.

[58] L. Plaza, C. Colina, B. D. Ancos, C. Sánchez-Moreno, and M. Pilar Cano, "Influence of ripening and astringency on carotenoid content of high-pressure treated persimmon fruit (Diospyros kaki L.)," Food Chemistry, vol. 130, no. 3, pp. 591-597, 2012.

[59] T. Niikawa, T. Suzuki, T. Ozeki, M. Kato, and Y. Ikoma, "Characteristics of carotenoid accumulation during maturation of the Japanese persimmon 'Fuyu,' Horticultural Research, vol. 6, pp. 251-256, 2007 (Japanese).

[60] G. Britton, "Structure and properties of carotenoids in relation to function," The FASEB Journal, vol. 9, no. 15, pp. 1551-1558, 1995.

[61] H. G. Daood, P. Biacs, B. Czinkotai, and Á. Hoschke, "Chromatographic investigation of carotenoids, sugars and organic acids from Diospyros kaki fruits," Food Chemistry, vol. 45, no. 2, pp. 151-155, 1992.

[62] I.-C. Jang, E.-K. Jo, S.-M. Bae et al., "Antioxidant activity and fatty acid composition of four different persimmon seeds," Food Science and Technology Research, vol. 16, no. 6, pp. 577-584, 2010.

[63] J. A. Menendez, L. Vellon, R. Colomer, and R. Lupu, "Oleic acid, the main monounsaturated fatty acid of olive oil, suppresses Her-2/neu (erbB-2) expression and synergistically enhances the growth inhibitory effects of trastuzumab (Herceptin) in breast cancer cells with Her-2/neu oncogene amplification," Annals of Oncology, vol. 16, no. 3, pp. 359-371, 2005.

[64] W. C. Willett, "The role of dietary n-6 fatty acids in the prevention of cardiovascular disease," Journal of Cardiovascular Medicine, vol. 8, no. 1, pp. S42-S45, 2007.

[65] K. Kawakami, S. Aketa, H. Sakai, Y. Watanabe, H. Nishida, and M. Hirayama, "Antihypertensive and vasorelaxant effects of water-soluble proanthocyanidins from persimmon leaf tea in spontaneously hypertensive rats," Bioscience, Biotechnology and Biochemistry, vol. 75, no. 8, pp. 1435-1439, 2011.

[66] G. Chen, J. Xue, S.-X. Xu, and R.-Q. Zhang, "Chemical constituents of the leaves of Diospyros kaki and their cytotoxic effects," Journal of Asian Natural Products Research, vol. 9, no. 4, pp. 347-353, 2007.

[67] S. Singh and H. Joshi, "Diospyros kaki (Ebenaceae): a review," Asian Journal of Research in Pharmaceutical Science, vol. 1, no. 3, pp. 55-58, 2011.

[68] J. L. Navarro, A. Tárrega, M. A. Sentandreu, and E. Sentandreu, "Partial purification and characterization of polyphenol oxidase from persimmon," Food Chemistry, vol. 157, pp. 283-289, 2014.
[69] O. V. Zillich, U. Schweiggert-Weisz, P. Eisner, and M. Kerscher, "Polyphenols as active ingredients for cosmetic products," International Journal of Cosmetic Science, vol. 37, no. 5, pp. 455464, 2015.

[70] H. Palafox-Carlos, J. F. Ayala-Zavala, and G. A. GonzálezAguilar, "The role of dietary fiber in the bioaccessibility and bioavailability of fruit and vegetable antioxidants," Journal of Food Science, vol. 76, no. 1, pp. R6-R15, 2011.

[71] A. Ratz-Łyko, J. Arct, S. Majewski, and K. Pytkowska, "Influence of polyphenols on the physiological processes in the skin," Phytotherapy Research, vol. 29, no. 4, pp. 509-517, 2015.

[72] J. Sun, Y.-F. Chu, X. Wu, and R. H. Liu, "Antioxidant and antiproliferative activities of common fruits," Journal of Agricultural and Food Chemistry, vol. 50, no. 25, pp. 7449-7454, 2002.

[73] E. Sentandreu, M. Cerdán-Calero, J. M. Halket, and J. L. Navarro, "Rapid screening of low-molecular-weight phenols from persimmon (Diospyros kaki) pulp using liquid chromatography/UV-visible/electrospray mass spectrometry analysis," Journal of the Science of Food and Agriculture, vol. 95, pp. 16481654, 2015.

[74] L. Bravo, "Polyphenols: chemistry, dietary sources, metabolism, and nutritional significance," Nutrition Reviews, vol. 56, no. 11, pp. 317-333, 1998.

[75] T. Akagi, Y. Suzuki, A. Ikegami et al., "Condensed tannin composition analysis in persimmon (Diospyros kaki Thunb.) fruit by acid catalysis in the presence of excess phloroglucinol," Journal of the Japanese Society for Horticultural Science, vol. 79, no. 3, pp. 275-281, 2010.

[76] C. Li, R. Leverence, J. D. Trombley et al., "High molecular weight persimmon (Diospyros kaki L.) proanthocyanidin: a highly galloylated, a-linked tannin with an unusual flavonol terminal unit, myricetin," Journal of Agricultural and Food Chemistry, vol. 58, no. 16, pp. 9033-9042, 2010.

[77] C. A. Rice-Evans, N. J. Miller, and G. Paganga, "Structureantioxidant activity relationships of flavonoids and phenolic acids," Free Radical Biology and Medicine, vol. 20, no. 7, pp. 933956, 1996.

[78] R. Tsao, "Chemistry and biochemistry of dietary polyphenols," Nutrients, vol. 2, no. 12, pp. 1231-1246, 2010.

[79] S. Uchida, H. Ohta, R. Edamatsu, M. Hiromatsu, A. Mori, and G. I. Nomaka, "Persimmon tannin prolongs life span of strokeprone spontaneously hypertensive rats (SHRSP) by acting as a free-radical scavenger," in New Horizons in Preventing Cardiovascular Diseases, Y. Yamori and T. Strasser, Eds., pp. 15-17, Academic Press, Amsterdam, The Netherlands, Elsevier, New York, NY, USA, 1989.

[80] S. Uchida, H. Ohta, M. Niwa et al., "Prolongation of life span of stroke-prone spontaneously hypertensive rats (SHRSP) ingesting persimmon tannin," Chemical and Pharmaceutical Bulletin, vol. 38, no. 4, pp. 1049-1052, 1990.

[81] S. Gorinstein, G. W. Kulasek, E. Bartnikowska et al., “The influence of persimmon peel and persimmon pulp on the lipid metabolism and antioxidant activity of rats fed cholesterol," Journal of Nutritional Biochemistry, vol. 9, no. 4, pp. 223-227, 1998.

[82] K. Matsumoto, A. Kadowaki, N. Ozaki et al., "Bile acid-binding ability of kaki-tannin from young fruits of persimmon (Diospyros kaki) in vitro and in vivo," Phytotherapy Research, vol. 25, no. 4, pp. 624-628, 2011.

[83] K. Ueda, R. Kawabata, T. Irie, Y. Nakai, Y. Tohya, and T. Sakaguchi, "Inactivation of pathogenic viruses by plant-derived tannins: strong effects of extracts from persimmon (Diospyros 
kaki) on a broad range of viruses," PLoS ONE, vol. 8, no. 1, Article ID e55343, 10 pages, 2013.

[84] H. Suzuki, M. Konishi, M. Kimura, T. Mori, M. Suzuki, and T. Ikemi, "Inhibitory effects of Diospyros kaki THUNB. Extracts in dental caries in rats," Japanese Journal of Conservative Dentistry, vol. 50, no. 2, pp. 140-145, 2007.

[85] S. Sakanaka, Y. Tachibana, and Y. Okada, "Preparation and antioxidant properties of extracts of Japanese persimmon leaf tea (Kakinoha-cha)," Food Chemistry, vol. 89, no. 4, pp. 569-575, 2005.

[86] M. Hosny and J. P. N. Rosazza, "Novel oxidations of (+)-catechin by horseradish peroxidase and laccase," Journal of Agricultural and Food Chemistry, vol. 50, no. 20, pp. 5539-5545, 2002.

[87] J.-I. Inokuchi, H. Okabe, T. Yamauchi, and A. Nagamatsu, "Inhibitors of angiotensin converting enzyme in crude drugs," Chemical and Pharmaceutical Bulletin, vol. 32, no. 9, pp. 36153619, 1984.

[88] Y. Tian, B. Zou, L. Yang et al., "High molecular weight persimmon tannin ameliorates cognition deficits and attenuates oxidative damage in senescent mice induced by d-galactose," Food and Chemical Toxicology, vol. 49, no. 8, pp. 1728-1736, 2011.

[89] Y. Achiwa, H. Hibasami, H. Katsuzaki, K. Imai, and T. Komiya, "Inhibitory effects of persimmon (Diospyros kaki) extract and related polyphenol compounds on growth of human lymphoid leukemia cells," Bioscience, Biotechnology and Biochemistry, vol. 61, no. 7, pp. 1099-1101, 1997.

[90] J. Gross, Carotenoids, vol. 123, Academic Press, New York, NY, USA, 1987.

[91] B. De Ancos, E. Gonzalez, and M. P. Cano, "Effect of highpressure treatment on the carotenoid composition and the radical scavenging activity of persimmon fruit purees," Journal of Agricultural and Food Chemistry, vol. 48, no. 8, pp. 35423548, 2000.

[92] T. Matsuo and S. Ito, "The chemical structure of Kaki-tannin from immature fruit of the persimmon (Diospyros kaki L.)," Agricultural and Biological Chemistry, vol. 42, no. 9, pp. 1637$1643,1978$.

[93] S. Gorinstein, M. Zemser, M. Weisz et al., "Fluorometric analysis of phenolics in persimmons," Bioscience, Biotechnology and Biochemistry, vol. 58, no. 6, pp. 1087-1092, 1994.

[94] S. O. Lee, H. J. Lee, M. H. Yu, H. G. Im, and I. S. Lee, “Total polyphenol contents and antioxidant activities of methanol extracts from vegetables produced in Ullung Island," Korean Journal of Food Science and Technology, vol. 37, no. 2, pp. 233-240, 2005.

[95] U. V. Mallavadhani, A. K. Panda, and Y. R. Rao, "Pharmacology and chemotaxonomy of Diospyros," Phytochemistry, vol. 49, no. 4, pp. 901-951, 1998.

[96] G. Block, B. Patterson, and A. Subar, "Fruit, vegetables, and cancer prevention: a review of the epidemiological evidence," Nutrition and Cancer, vol. 18, no. 1, pp. 1-29, 1992.

[97] G. van Poppel, "Carotenoids and cancer: an update with emphasis on human intervention studies," European Journal of Cancer, vol. 29, no. 9, pp. 1335-1344, 1993.

[98] E. Giovannucci, A. Ascherio, E. B. Rimm, M. J. Stampfer, G. A. Colditz, and W. C. Willett, "Intake of carotenoids and retino in relation to risk of prostate cancer," Journal of the National Cancer Institute, vol. 87, no. 23, pp. 1767-1776, 1995.

[99] T. Johns, R. L. A. Mahunnah, P. Sanaya, L. Chapman, and T. Ticktin, "Saponins and phenolic content in plant dietary additives of a traditional subsistence community, the Batemi of Ngorongoro District, Tanzania," Journal of Ethnopharmacology, vol. 66, no. 1, pp. 1-10, 1999.
[100] Y. Zhang, X. Lu, Y. Zhang, L. Qin, and J. Zhang, "Sulfated modification and immunomodulatory activity of water-soluble polysaccharides derived from fresh Chinese persimmon fruit," International Journal of Biological Macromolecules, vol. 46, no. 1, pp. 67-71, 2010.

[101] Y.-J. Moon and Y.-S. Cha, "Effects of persimmon-vinegar on lipid metabolism and alcohol clearance in chronic alcohol-fed rats," Journal of Medicinal Food, vol. 11, no. 1, pp. 38-45, 2008.

[102] H. S. Ahn, T. I. Jeon, J. Y. Lee, S. G. Hwang, Y. Lim, and D. K. Park, "Antioxidative activity of persimmon and grape seed extract: in vitro and in vivo," Nutrition Research, vol. 22, no. 11, pp. 1265-1273, 2002.

[103] H. Itamurah, N. Murakami, and H. Nagamatsu, "Property of kaki-tannin as a functional composition in persimmon fruit flesh and leaves and its solubility in artificial stomach liquid," in Proceedings of the 27th International Horticultural Congress \& Exhibition (IHC '06), vol. 8, pp. 265-267, August 2006.

[104] K. A. Steinmetz and J. D. Potter, "Vegetables, fruit, and cancer prevention: a review," Journal of the American Dietetic Association, vol. 96, no. 10, pp. 1027-1039, 1996.

[105] A. N. Nagappa, P. A. Thakurdesai, N. V. Rao, and J. Singh, "Antidiabetic activity of Terminalia catappa Linn fruits," Journal of Ethnopharmacology, vol. 88, no. 1, pp. 45-50, 2003.

[106] K. Datta, S. Sinha, and P. Chattopadhyay, "Reactive oxygen species in health and disease," National Medical Journal of India, vol. 13, no. 6, pp. 304-310, 2000.

[107] R. R. Holman and R. C. Turner, "Oral agents and insulin in the treatment of NIDDM," in Textbook of Diabetes, J. Williams, Ed., pp. 407-469, Blackwell Press, Oxford, UK, 1991.

[108] F. Giacco and M. Brownlee, "Oxidative stress and diabetic complications," Circulation Research, vol. 107, no. 9, pp. 1058$1070,2010$.

[109] B. K. Rao, M. M. Kesavulu, R. Giri, and C. A. Rao, "Antidiabetic and hypolipidemic effects of Momordicacymbalaria Hook. fruit powder in alloxan-diabetic rats," Journal of Ethnopharmacology, vol. 67, no. 1, pp. 103-109, 1999.

[110] J. K. Grover, V. Vats, V. Rathi, and S. S. Dawar, “Traditional Indian anti-diabetic plants attenuate progression of renal damage in streptozotocin induced diabetic mice," Journal of Ethnopharmacology, vol. 76, no. 3, pp. 233-238, 2001.

[111] R. K. Gupta, A. N. Kesari, P. S. Murthy, R. Chandra, V. Tandon, and G. Watal, "Hypoglycemic and antidiabetic effect of ethanolic extract of leaves of Annona squamosa L. in experimental animals," Journal of Ethnopharmacology, vol. 99, no. 1, pp. 7581, 2005.

[112] S. Gupta, N. Ahmad, A.-L. Nieminen, and H. Mukhtar, "Growth inhibition, cell-cycle dysregulation, and induction of apoptosis by green tea constituent (-)-epigallocatechin-3-gallate in androgen-sensitive and androgen-insensitive human prostate carcinoma cells," Toxicology and Applied Pharmacology, vol. 164, no. 1, pp. 82-90, 2000.

[113] T. Yokozawa, Y. A. Kim, H. Y. Kim, Y. A. Lee, and G.-I. Nonaka, "Protective effect of persimmon peel polyphenol against high glucose-induced oxidative stress in LLC-PK1 cells," Food and Chemical Toxicology, vol. 45, no. 10, pp. 1979-1987, 2007. 
[114] M. S. Brewer, "Natural antioxidants: sources, compounds, mechanisms of action, and potential applications," Comprehensive Reviews in Food Science and Food Safety, vol. 10, no. 4, pp. 221-247, 2011.

[115] K. Kawakami, H. Nishida, N. Tatewaki, Y. Nakajima, T. Konishi, and M. Hirayama, "Persimmon leaf extract inhibits the ATM activity during DNA damage response induced by Doxorubicin in A549 lung adenocarcinoma cells," Bioscience, Biotechnology and Biochemistry, vol. 75, no. 4, pp. 650-655, 2011.

[116] D. Steinberg, S. Parthasarathy, T. E. Carew, J. C. Khoo, and J. L. Witztum, "Beyond cholesterol: modifications of low-density lipoprotein that increase its atherogenicity," The New England Journal of Medicine, vol. 320, no. 14, pp. 915-924, 1989.

[117] P. M. Kris-Etherton and C. L. Keen, "Evidence that the antioxidant flavonoids in tea and cocoa are beneficial for cardiovascular health," Current Opinion in Lipidology, vol. 13, no. 1, pp. 41-49, 2002.

[118] C. Manach, A. Mazur, and A. Scalbert, "Polyphenols and prevention of cardiovascular diseases," Current Opinion in Lipidology, vol. 16, no. 1, pp. 77-84, 2005.

[119] J. W. Anderson, B. M. Smith, and N. J. Gustafson, "Health benefits and practical aspects of high-fiber diets," American Journal of Clinical Nutrition, vol. 59, no. 5, pp. 1242-1247, 1994.

[120] D. Kromhout, A. Menotti, H. Kesteloot, and S. Sans, "Prevention of coronary heart disease by diet and lifestyle, evidence from prospective cross-cultural, cohort, and intervention studies," Circulation, vol. 105, no. 7, pp. 893-898, 2002.

[121] E. B. Rimm, M. J. Stampfer, A. Ascherio, E. Giovannucci, G. A. Colditz, and W. C. Willett, "Vitamin E consumption and the risk of coronary heart disease in men," The New England Journal of Medicine, vol. 328, no. 20, pp. 1450-1456, 1993.

[122] L. Dauchet, J. Ferrières, D. Arveiler et al., "Frequency of fruit and vegetable consumption and coronary heart disease in France and Northern Ireland: the prime study," British Journal of Nutrition, vol. 92, no. 6, pp. 963-972, 2004.

[123] S. Gorinstein, G. W. Kulasek, E. Bartnikowska et al., "The effects of diets, supplemented with either whole persimmon or phenolfree persimmon, on rats fed cholesterol," Food Chemistry, vol. 70, no. 3, pp. 303-308, 2000.

[124] M. G. L. Hertog, E. J. M. Feskens, P. C. H. Hollman, M. B. Katan, and D. Kromhout, "Dietary antioxidant flavonoids and risk of coronary heart disease: the Zutphen Elderly study," The Lancet, vol. 342, no. 8878, pp. 1007-1011, 1993.

[125] H. Seo, B. D. Jeon, and R. Sungpil, "Persimmon vinegar ripening with the mountain-cultivated ginseng ingestion reduces blood lipids and lowers inflammatory cytokines in obese adolescents," Journal of Exercise Nutrition and Biochemistry, vol. 19, no. 1, pp. 1-10, 2015.

[126] R. H. Liu, "Potential synergy of phytochemicals in cancer prevention: mechanism of action," Journal of Nutrition, vol. 134, no. 12, supplement, pp. 3479S-3485S, 2004.

[127] S. T. Mayne, "Antioxidant nutrients and chronic disease: use of biomarkers of exposure and oxidative stress status in epidemiologic research," Journal of Nutrition, vol. 133, no. 3, pp. 933s940s, 2003.

[128] H. Tapiero, D. M. Townsend, and K. D. Tew, "The role of carotenoids in the prevention of human pathologies," Biomedicine and Pharmacotherapy, vol. 58, no. 2, pp. 100-110, 2004.

[129] J. Tao and S. L. Zhang, "Metabolism of carotenoid and its regulation in garden crop," Journal of Zhejiang University (Agriculture \& Life Sciences), vol. 29, pp. 585-590, 2003.
[130] W. Miki, "Biological functions and activities of animal carotenoids," Pure and Applied Chemistry, vol. 63, no. 1, pp. 141-146, 1991.

[131] H. Fujiki, "Green tea: health benefits as cancer preventive for humans," Chemical Record, vol. 5, no. 3, pp. 119-132, 2005.

[132] A. P. George and S. Redpath, "Health and medicinal benefits of persimmon fruit: a review," Advances in Horticultural Science, vol. 22, no. 4, pp. 244-249, 2008.

[133] T. Hussain, S. Gupta, V. M. Adhami, and H. Mukhtar, "Green tea constituent epigallocatechin-3-gallate selectively inhibits COX-2 without affecting COX-1 expression in human prostate carcinoma cells," International Journal of Cancer, vol. 113, no. 4, pp. 660-669, 2005.

[134] Y.-C. Wang and U. Bachrach, "The specific anti-cancer activity of green tea (-)-epigallocatechin-3-gallate (EGCG)," Amino Acids, vol. 22, no. 2, pp. 131-143, 2002.

[135] O. Takayuki, "Persimmons: your healthy autumn treats," Asahikawa Information, vol. 108, pp. 1-2, 2005.

[136] T. Fukuda and H. Shibata, "Persimmon calyx extracts as anticonvulsants and to alleviate the side effects of barbituric acid compounds," Patent Japanease Kokai Tokkyo Koho, vol. 6, pp. 649-653, 1994.

[137] T. Matsuno, "Xanthophylls as precursors of retinoids," Pure and Applied Chemistry, vol. 63, no. 1, pp. 81-88, 1991.

[138] N. Gato, A. Kadowaki, N. Hashimoto, S.-I. Yokoyama, and K. Matsumoto, "Persimmon fruit tannin-rich fiber reduces cholesterol levels in humans," Annals of Nutrition and Metabolism, vol. 62, no. 1, pp. 1-6, 2013.

[139] A. Nagao, "Absorption and function of dietary carotenoids," Forum of Nutrition, vol. 61, pp. 55-63, 2009.

[140] P. D. Fraser and P. M. Bramley, "The biosynthesis and nutritional uses of carotenoids," Progress in Lipid Research, vol. 43, no. 3, pp. 228-265, 2004.

[141] D. Fusco, G. Colloca, M. R. Lo Monaco, and M. Cesari, "Effects of antioxidant supplementation on the aging process," Clinical Interventions in Aging, vol. 2, no. 3, pp. 377-387, 2007.

[142] J. M. Seddon, U. Ajan, and R. D. Sperduto, "Dietary carotenoids, vitamins $\mathrm{A}, \mathrm{C}$ and $\mathrm{E}$ and advance age-related macular degeneration. Eye Disease Case Study Group," Journal of American Medical Association, vol. 272, no. 18, pp. 1413-1420, 1992.

[143] B.-J. An, J.-H. Kwak, J.-M. Park et al., "Inhibition of enzyme activities and the antiwrinkle effect of polyphenol isolated from the persimmon leaf (Diospyros kaki folium) on human skin," Dermatologic Surgery, vol. 31, no. 7, pp. 848-854, 2005.

[144] H. Arakawa, M. Takasaki, N. Tajima, H. Fukamachi, and T. Igarashi, "Antibacterial activities of persimmon extracts relate with their hydrogen peroxide concentration," Biological and Pharmaceutical Bulletin, vol. 37, no. 7, pp. 1119-1123, 2014.

[145] S. D. Ladas, D. Kamberoglou, G. Karamanolis, J. Vlachogiannakos, and I. Zouboulis-Vafiadis, "Systematic review: CocaCola can effectively dissolve gastric phytobezoars as a first-line treatment," Alimentary Pharmacology and Therapeutics, vol. 37, no. 2, pp. 169-173, 2013.

[146] T. J. Cifuentes, C. R. Robles, P. P. Parrilla et al., "Polyphenols and health: what compounds are involved?" Nutrition, Metabolism and Cardiovascular Diseases, vol. 20, no. 1, pp. 1-6, 2010.

[147] J. Gayà, L. Barranco, A. Llompart, J. Reyes, and A. Obrador, "Persimmon bezoars: a successful combined therapy," Gastrointestinal Endoscopy, vol. 55, no. 4, pp. 581-583, 2002.

[148] P. G. Hayes and O. D. Rotstein, "Gastrointestinal phytobezoars: presentation and management," Canadian Journal of Surgery, vol. 29, no. 6, pp. 419-420, 1986. 
[149] M. M. Krausz, E. Z. Moriel, A. Ayalon, D. Pode, and A. L. Durst, "Surgical aspects of gastrointestinal persimmon phytobezoar treatment," The American Journal of Surgery, vol. 152, no. 5, pp. 526-530, 1986.

[150] P. Walker-Renard, "Update on the medicinal management of phytobezoars," The American Journal of Gastroenterology, vol. 88, no. 10, pp. 1663-1666, 1993.

[151] S. S. Ha, H. S. Lee, M. K. Jung et al., "Acute intestinal obstruction caused by a persimmon phytobezoar after dissolution therapy with Coca-Cola," The Korean Journal of Internal Medicine, vol. 22, no. 4, pp. 300-303, 2007.

[152] J. Han, S. Kang, R. Choue et al., "Free radical scavenging effect of Diospyros kaki, Laminaria japonica and Undaria pinnatifida," Fitoterapia, vol. 73, no. 7-8, pp. 710-712, 2002. 

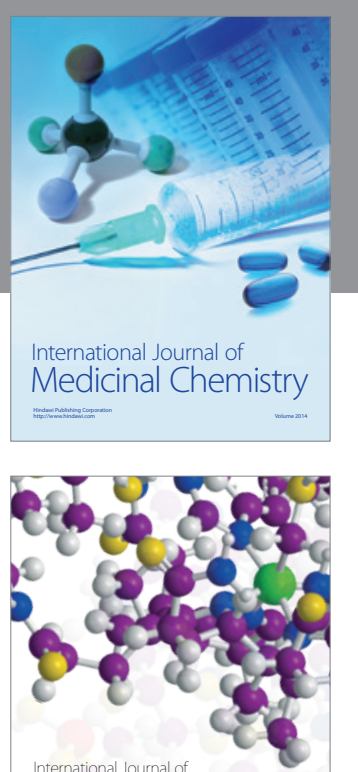

Carbohydrate Chemistry

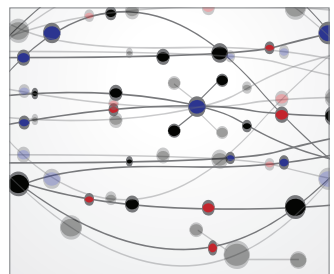

The Scientific World Journal
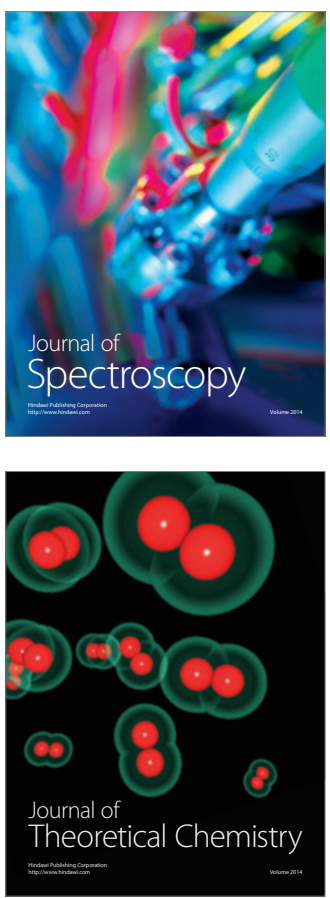
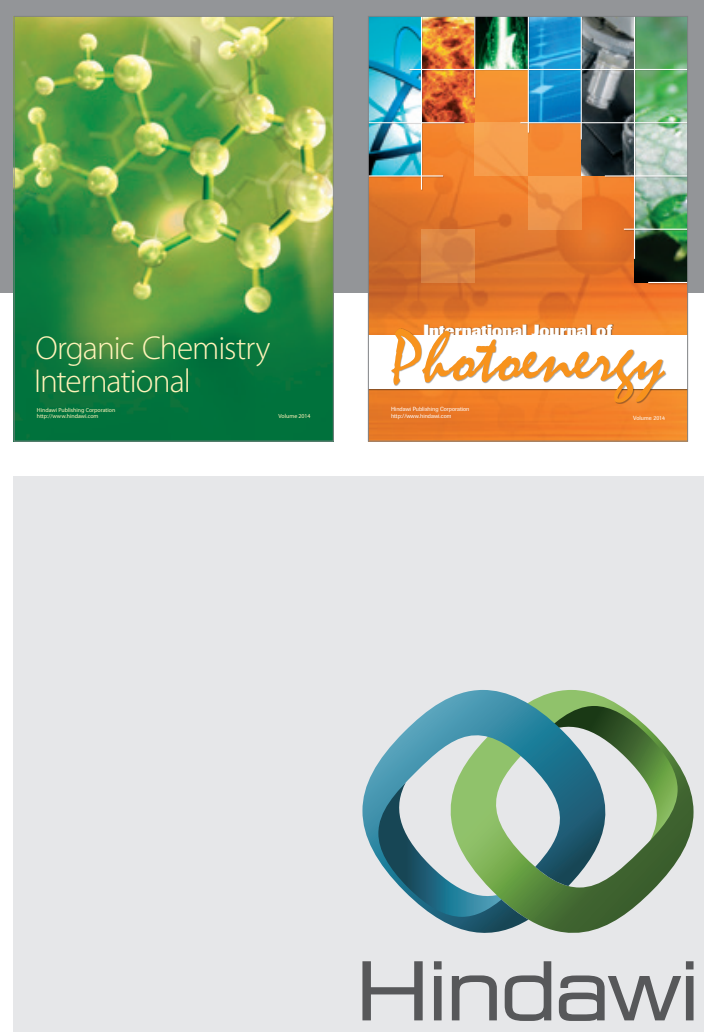

Submit your manuscripts at

http://www.hindawi.com

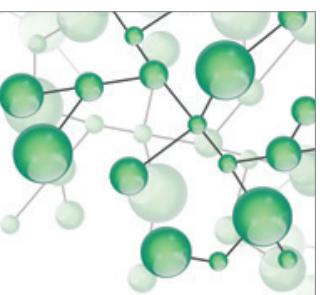

International Journal of

Inorganic Chemistry

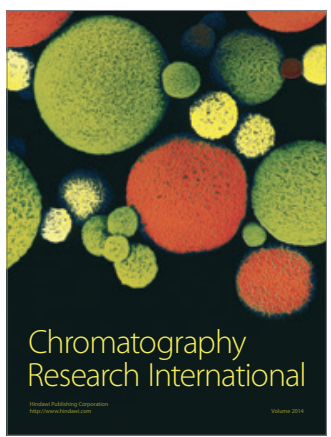

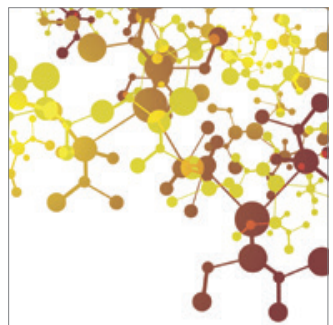

Applied Chemistry
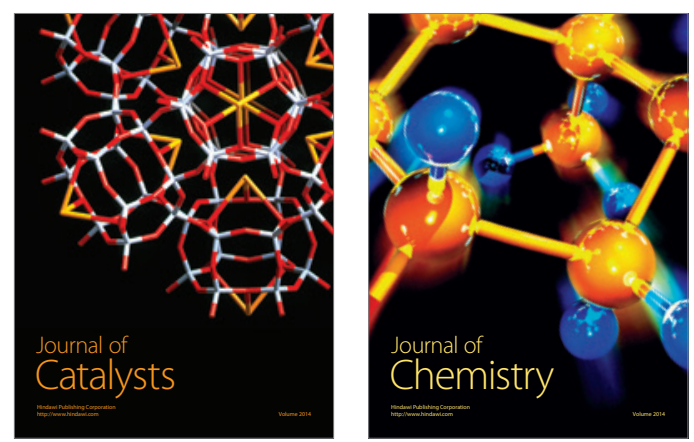
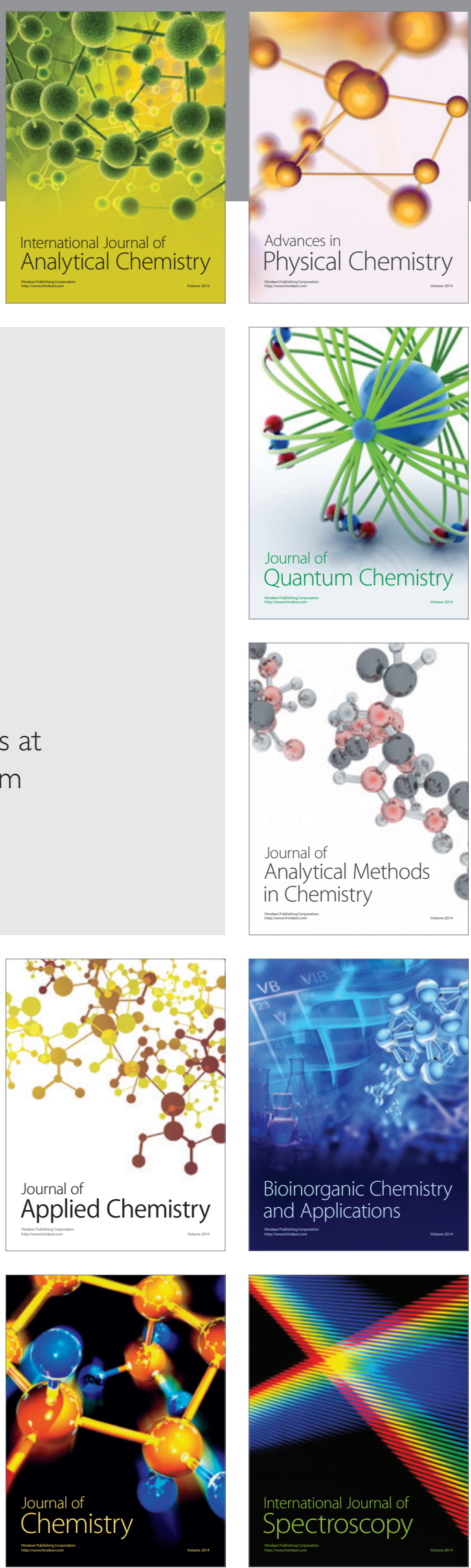